\title{
Os selos, outros, últimos, de Herberto Helder: pelo sopro da criação à harmonia
}

\author{
João Amadeu Oliveira Carvalho da Silva \\ Universidade Católica Portuguesa (Braga)
}

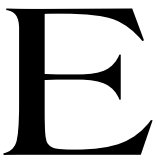

m nota inicial ao livro Do mundo, Herberto Helder afirma:

"Inserem-se aqui Os selos, outros, últimos [...], deveriam aparecer junto a Os selos em Poesia toda, ed. 1990, por pertencerem ao mesmo impulso de escrita e com eles formarem um ciclo completo. Aparecem agora em livro e remetem-se ao volume onde estariam melhor". ${ }^{1}$ Serão os seis outros e últimos selos a juntar aos doze anteriores que permitirão a conclusão de um percurso que, desde o seu início, se assumiu pela capacidade simbólica, pela abrangência e energia vulcânica imposta às imagens, por diálogos sugestivos com o grande código da Bíblia. Os poemas de Os selos, datados de 1989, representaram a base de trabalho de uma dissertação de mestrado que apresentámos no início de $1995 .^{2}$ Numa última nota dessa prova académica mostrávamos interesse em desenvolver um estudo de Os selos, outros, últimos, que, datados de Novembro-Dezembro de 1990 e vindos a lume pela primeira vez na folha editorial da Assírio \& Alvim A phala, n 27, em Dezembro de 1991, foram publicados no final do ano de 1994 e posteriormente incluídos na Poesia toda (1996). De Os selos desenvolveremos alguns aspectos que encontrem eco ou tenham sequência nos poemas de $O s$ selos, outros, últimos; procuraremos entender a relação entre eles, perscrutar aprofundamentos de sentidos, variações e passos do ciclo que termina com os últimos selos. O diálogo com o intertexto bíblico representará um modo de avizinhar os dois grupos de poemas; surgirão,

\footnotetext{
${ }^{1}$ HELDER, 1994b, p. 6.

${ }^{2}$ SILVA, 2000.
} 
no entanto, outros elementos que aproximarão os dezoito textos poéticos que se encontram determinados pelos "selos" apocalípticos e se inscrevem numa procura pelas palavras, enquanto imagem de um entendimento em profundidade das coisas e do corpo.

\section{Uma incursão por Os selos}

Realçámos dos doze poemas que compõem este livro, entre outros sentidos de leitura, relações com o intertexto bíblico do Apocalipse, ${ }^{3}$ sendo evidenciada a necessidade do caos, sugerida pelo livro bíblico, como forma de entender um sentido depurado e superior das coisas e das palavras, saindo estas purificadas à custa da anulação ou violentação dos limites dos seus sentidos. Destacável, nessa relação intertextual, é por exemplo o que se pode ler logo no primeiro poema do livro, quando o poeta refere "a puta escarlate ao meio dos cornos da besta", ${ }_{4}^{4}$ dialogando impressivamente com a imagem de "uma mulher sentada sobre uma besta de cor escarlate, coberta de nomes blasfematórios, com sete cabeças e dez chifres". ${ }^{5}$ Verifica-se neste exemplo um desvio do centro de focalização, como aliás se torna comum nas relações intertextuais herbertianas, com o aproveitamento da parte sugestiva do intertexto, e aqui numa perspectiva parodística.

A criança é também um exemplo que nos parece significativo pela presença abundante ao longo dos diversos poemas. Mas esta criança, para além de manter alguma relação com o "Cordeiro", o Salvador que nascerá da mulher que está a dar à luz $z^{6}$ na visão apocalíptica da Bíblia, é um ser que apresenta outra amplitude, distintas variações ou ramificações associadas à energia, à violência, simbolicamente próximas do "leão": "Criança ou leão dançando de porta a porta" (p. 563), ou ainda "leão, estrela, criança louca" (p. 562). Os animais que nesta poesia se colocam em plano de igualdade com a criança inscrevem-se no espaço das

${ }^{3}$ SILVA, 2000, p. 13-52.

${ }^{4}$ HELDER, 1995, p. 549. Ao longo do artigo, quando citarmos Poesia Toda (1996), de Herberto Helder, indicaremos entre parêntesis somente a página do livro.

${ }^{5}$ Ap 17, 3.

${ }^{6}$ Ap 12, 1-18. 
"montanhas das áfricas / redivivas -" (p. 559): o poeta desloca o foco espacial da Jerusalém celeste do Apocalipse para o espaço africano, de forma a recolher do potencial mítico e das suas vivências pessoais de África uma profunda relação de sentidos entre a sua recôndita e antiquíssima origem e o espaço iniciático da poesia. Aí, a violência e o caos convivem, num ambiente sagrado, com a inocência e a purificação dos sentidos das coisas e das palavras transbordantes: "Como se transborda / de coisa a coisa escrita africanamente!" (p. 556). Jerusalém celeste ou o espaço de harmonia situar-se-á para lá da destruição pelo fogo, tornar-se-á um espaço simbólico, construído à custa dos passos na combinatória de sentidos esquivos e difusos.

Se a necessidade de unidade e de harmonia se tornam evidentes, o caos, como momento inspirador e promotor dessa estabilidade superior, "[...] nunca impediu nada, foi sempre um alimento inebriante" (p. 549). Associada a essa procura, a linguagem essencialmente metafórica impõe à palavra, enquanto nome das coisas, camadas de sentidos que a distanciam infinitamente da linguagem comum e colocam o leitor perante o quase não sentido, o momento original da palavra em que o nome é a coisa, em que o toque da mão na coisa representa a unidade absoluta com a coisa: mão, toque e coisa são um único elemento. Podemos recordar, nesta perspectiva, a "máscara" (p. 556-557, 567), que simboliza um objecto que situado categorialmente num ambiente e dimensão superior transporta consigo a violência, a energia, o estatuto sagrado de ser mais do que um mero objecto humano, uma realidade que em si contém a unidade do rosto e os múltiplos sem-sentidos desse rosto. As vivências invisíveis que o rosto transporta consigo, com a anulação do tempo, tornar-se-ão intensas e absolutamente presentes pela imposição única da "máscara": "levo a máscara, / levo-a deste mundo. / Quem sabe se o mundo estremece pela força da máscara pequena" (p. 556). A "máscara", de algum modo, funciona como a palavra: esta contém em si, em simultâneo, uma realidade que é a da sua materialidade, a composição dos seus elementos, a sua fisicidade absolutamente indiferente ao sentido secreto, oculto e iniciático. No entanto, a palavra é também capaz de sugerir o que não mostra, indo muito para além da sua superfície, anulando as linhas que a definem na sua particularidade, e, por se afastar dessa especificidade castradora, acaba por dizer mais e abrir para sentidos múltiplos. A "máscara" sugere a superfície das coisas e das palavras que, retiradas dos seus contextos culturais e linguísticos, passam a exigir, da 
parte de quem as toma, uma iniciação, uma preparação, uma depuração conseguida à custa da anulação dos sentidos culturais com que lidamos quotidianamente: "Levo a máscara, disse eu. Quando pus os dedos / na frase, a frase / sangrava. Tinha aquele lanho, alguém cosera tudo com agrafes de marfim / - palavras a marfim e sangue. Disse: levo-a comigo" (p. 556-557).

\section{Dos primeiros doze selos aos seis últimos}

Os seis últimos poemas desenvolvem, como seria de esperar, algumas das isotopias presentes no anterior conjunto de poemas. Encontra-se, no entanto, nestes textos que apresentam uma amplitude discursiva semelhante aos primeiros selos e não retomada em Do mundo (1994), um reforço de determinadas imagens que merecerão uma atenção particular e que permitem a compreensão de um rumo e uma determinada progressão neste terceiro agrupamento de seis poemas (seis poemas vezes três são dezoito).

No Apocalipse, o número seis teria uma significação claramente pejorativa: seria o número do pecado [...]. Da mesma forma, o falso profeta, o Anticristo do Apocalipse, terá... a marca, o nome da Besta ou o número de seu nome. Quem é inteligente calcule o número da Besta, pois é um número de homem: seu número é $666(13,17-18){ }^{7}$

Mesmo que não tomando à letra as sugestões de Chevalier, entende-se nestes poemas de Herberto Helder um diálogo complexo entre a harmonia e o caos, como teremos oportunidade de estudar. A este propósito, e para compreender a carga simbólica do número seis, recorde-se a importância do poema sexto de Os selos, pela referência aos espaços de elevação: "Montanhas das áfricas, / montanhas das árvores que sangram" (p. 558) e no final do mesmo poema: "[...] a realeza / do poema animal - leopardo e leão. Oh, / cantam em música humana, eles, no trono / das montanhas das áfricas / redivivas -" (p. 559). Entender-seá igualmente a centralidade temática do último poema dos seis textos, quando o abordarmos no final deste estudo. Os títulos Os selos e Os selos,

${ }^{7}$ CHEVALIER; GHEERBRANT, 1992, p. 809. 
outros, últimos realçam a bipolaridade simbólica do selo, dado que este potencia a dupla possibilidade de selar e de quebrar o selo. O selo existe para selar, mas verdadeiramente a sua função é a de selar o que pode ser desselado por alguém que se encontre habilitado para tal. Para além da aproximação aos sete selos do Apocalipse, a atitude de quebrar os selos permite, na poesia herbertiana, a consecução dos objectivos últimos do processo criativo: "quebram-se os selos aparecem / os prodígios" (p. 549). Neste sentido, atente-se no percurso e no facto de se assumirem os selos do segundo grupo como os últimos e definitivos, direccionando a expectativa da leitura para o termo da viagem.

\section{Da proposta apocalíptica à visão genesíaca}

Se já esboçámos a relação intertextual com o Apocalipse, através da referência a algumas passagens tanto dos doze poemas como dos seis últimos, torna-se interessante também entender o Génesis como intertexto igualmente privilegiado, capaz de representar de algum modo o pólo oposto ao do Apocalipse, embora também estes dois livros bíblicos se possam ler de forma combinada. A mulher, embora com variações significativas, poderá aproximar os dois conjuntos de textos com esse intuito simultaneamente apocalíptico e genesíaco; ao lado do elemento feminino, o caos e a criação completam-se, sequenciam-se e adquirem sentido pleno se articulados. Também no Génesis, é do caos que surgirá a vida, a vontade divina criará a harmonia a partir da matéria inerte: "A terra era informe e vazia. As trevas cobriam o abismo". 8

$\mathrm{Na}$ verdade, para além daquelas referências, podem destacar-se diversas presenças ao longo dos primeiros doze poemas, enquanto elementos promotores daquele diálogo. Realçaríamos a "fábula", como representação de uma narrativa elementar, capaz de esboçar miticamente a primordialidade da experiência humana. Logo, no terceiro poema de Os selos, "os elementos puros trabalham na fábula do mundo" (p. 552), encontrando-se a purificação da matéria associada, deste modo, ao acto de criação. Relacionado com o momento iniciático e genesíaco, encontrámos igualmente as referências ao "poema da criação" (p. 552, 553): "Amor, se

\footnotetext{
${ }^{8} \mathrm{Gn} 1,2$.
} 
a porta se abrisse no bosque e entrasse o leopardo / entoando o poema da criação, se a cantaria de ouro se fendesse / no escuro" (552) e ainda "Morre-se de ver a pintura, respira-se / cara a cara, à porta o leopardo entoa o poema da criação" (p. 552-553). O protagonismo do acto criador recai aqui sobre a composição poética e em especial sobre o "leopardo" que entoa esse poema da criação, transferência compreensível, quando se destaca o espaço privilegiado da "áfrica" pela capacidade de representar um contacto imediato com a raiz da vida, ainda na sua pureza primordial.

Neste contexto, "o poema da criação" seria uma fábula, onde o protagonista "leopardo" assumiria a narrativa exemplar, transmitiria aos homens a sabedoria da violência inocente, a necessidade do caos antes do momento criativo. No Génesis, "O Senhor Deus formou o homem do pó da terra e insuflou-lhe pelas narinas o sopro da vida, e o homem transformou-se num ser vivo": o "poema da criação" substitui a criação do homem e em lugar do leopardo encontra-se Deus. Entre o intertexto bíblico e o texto herbertiano há, em comum, o momento de inspiração ou o elemento primordial ar, pelo sopro, que permite algum paralelismo entre os dois actos criadores, porém, reformula-se a consciência da divindade com o acto criador centrado na violência da criação do poema.A aproximação ao intertexto do Génesis pode perscrutar-se ao longo de diversos poemas, considerando, por exemplo, as variações verbais de soprar, dada a pertinência desse verbo no contexto ideológico do texto bíblico. Em Os selos, o sentido iniciático, como já vimos, encontra-se associado aos animais, "Leopardos vivos debaixo das coroas, e os leões que alguém / soprou na boca" (p. 558): aqui, a acção de soprar está presente, embora não seja identificado o sujeito da acção, o protagonismo é conseguido à custa da palavra criadora. O sopro criador e divino nas narinas de Adão transforma-se aqui num sopro que promove o movimento, a alteração do comportamento ou a qualidade da atitude: "A oblíqua visita das coisas, aquela / murmuração de mundo quando se toca / com um braço a parte dos fogos, com o outro braço a parte / dos sopros que desarrumam a frase das coisas / e arrumam / coisa a coisa o estilo onde estás escrita" (p. 568). Nesta "oblíqua visita das coisas", o corpo assume uma importância significativa (noutra ocasião falávamos do

${ }^{9}$ Gn 2,7 . 
corpocentrismo, ${ }^{10}$ na obra de Herberto Helder), tendo num dos seus extremos o fogo e no outro o sopro: dois dos elementos primordiais igualmente recorrentes nesta poesia, o primeiro apocalíptico e purificador e o segundo genesíaco. O sopro, depois de desarrumar as coisas, arrumaas, representando esse arranjo o próprio estilo, enquanto marca específica e indelével do acto criador.

Passando para Os selos, outros, últimos, continuamos a encontrar significativas possibilidades de diálogo com o intertexto bíblico. A propósito dos nomes e da sua apetência para representarem as coisas e manter com elas uma intrínseca relação, questiona o poeta: "Como passarlhes tanta força, meter as mãos no idioma / torcer as tripas como soprar nos sacos quentes, transferir / o segredo?" (p. 577). À semelhança dos excertos que comentámos dos primeiros doze poemas, o sopro associase à criação do poema e em especial à criação do nome, "Alguns nomes são filhos vivos alguns ensinos de memória e dor" (p. 577), porque o nome já existente assume, pela específica utilização e pelo contexto distinto, uma nova identidade, renascendo: depois da purificação, sopra-se-lhe nas narinas ou na boca para que tenha vida, para que lhe seja transferido o "segredo", depois de reconhecido o caos torna-se necessária a criação divina, no Génesis, depois do reconhecimento do caos é fundamental a criação de um estilo, como afirma o autor, em Os passos em volta: "Há felizmente o estilo. Não calcula o que seja? Vejamos: o estilo é um modo subtil de transferir a confusão e violência da vida para o plano mental de uma unidade de significação". ${ }^{11}$

Prosseguindo com Os selos, outros, últimos, encontramos, ao longo de todo o terceiro poema, elementos simbólicos que se inscrevem no contexto da relação intertextual com o Génesis e de algum modo com o Apocalipse:

Um nome simples para nascer por fora dormir comer subir nos espelhos inocentes, e ser leve e amado abrir as portas. Tiram do forno o vidro em massa violenta trazem a cana dizem:

Mestre e depois o nome sem os elementos misteriosos. Ele sopra. Não infunde na matéria crispada essa força

\footnotetext{
${ }^{10}$ Cf. SILVA, 2004, p. 129.

${ }^{11}$ HELDER, 1994a, p. 9.
} 
extrema para morrer e renascer todos os dias: infunde-lhe o coração da forma. Vejam

- o quê? escutem

- o quê? ciclo o sangue talvez o ar inchando a carne

- a doce luz moldada atrás do nome: a cara?

Com as tripas. Diz-se:

que significa? Sonhou com a guerra? Sonhou

com o angélico e o demoníaco: um vento espigando as estrelas, o escuro por cima.

A boca árdua, quem a modula? Em redor da cana uma zona iluminada. Que centro?

que movimento? Uma volta atmosférica num astro uma

volta do astro no forno uma volta do forno

em si mesmo. Ele

toca a vibração do rosto no espelho a roupa crepita ele

morre todo o dia na sua roupa, devora

a ração humana das coisas: amor, comida, sono - o volume

hormonal

a queimadura.

Depois sopra - e o vidro respira do que ele respirou: mais

que oxigénio biografia mais

que memória

- respira de uma aceleração

do mundo, restituição, encarnação, assumpção, miraculação

da ordem nominal do mundo.

Arde no cérebro, tremem-lhe os dedos nos objectos.

Ele tem esse

nome dócil à máquina da vida se vai morrer com o nome

deslumbra pelo nome perfeito. Aquilo

- soprar na cana: dá-lhe um baptismo novo

um reinado um

segredo. Inaugural

quando lhe dizem: Mestre - e a palavra sem ar ele carrega

com o hausto o número inexplicável.

Por um nexo da fala pequena com a fala que se inspira de tudo:

não o seu

nome imovelmente

mas o nome do prodígio. O pneuma em cheio na estrela:

uma campânula, um jarro soprado.

Ele, abuso onde pessoas e coisas - transfunde os pulmões no vidro:

campânula e jarro são os pulmões do mundo.

E passa o vento de Deus eriçando o ouro em torno - (p. 579-580). 
Ao lermos um poema de Herberto Helder, sentimos dificuldade em abranger de forma organizada os aliciantes convites para aproximar os elementos simbólicos que se atropelam intempestivamente no texto; são excessivos os desafios, abrem-se imensas possibilidades, no entanto, torna-se necessário conter algumas das solicitações.

No poema citado, as entidades maiusculadas "Mestre" e "Deus" concentram, de algum modo, a atenção. Repare-se, porém, que imediatamente antes do primeiro daqueles vocábulos se encontra o verbo declarativo seguido de dois pontos e um travessão e do contexto do segundo vocábulo interessa o "vento" de quem Deus é o complemento determinativo: da primeira palavra realça-se a sua função do nome, parecendo bastar a sua enunciação para que de imediato o efeito se reflicta sobre o que lhe é circundante; relativamente à segunda palavra, refira-se a função reflectida na acção do "vento" ao qual se encontram associados variados vocábulos ao longo do poema.

À medida que se progride na leitura daquele texto poético, entendese a assunção de uma entidade na terceira pessoa do singular, identificável com o "Mestre", protagonista da acção criadora. Como que situado num espaço primordial, entende-se a potencialidade do que lhe está adjacente, torna-se necessário o gesto, o sopro sobre o nome que assume desde o início do poema uma evidente centralidade. Também no início da criação, no intertexto bíblico, torna-se fundamental o nome: "o Senhor Deus, após ter formado da terra todos os animais dos campos e todas as aves dos céus, conduziu-os até junto do homem, a fim de verificar como ele os chamaria, para que todos os seres vivos fossem conhecidos pelos nomes que o homem lhes desse". ${ }^{12}$ A valorização do nome ao longo do poema associa-se a uma igual preponderância da acção de soprar, verbo que tem merecido a nossa atenção, como vocábulo que mantém uma relação produtiva com o Génesis. Atentemos na recolha sequenciada dessa presença neste poema: "Ele sopra", "Depois sopra", "Aquilo / - soprar na cana" e finalmente "um jarro soprado". Esta recolha perspectiva uma relação interessante com a entidade que protagoniza a acção do verbo, dado que o sujeito da acção se vai diluindo ao longo daquela enumeração: de um sujeito identificado e presente passa a um sujeito ausente, de seguida transfere-se para um infinito substantivado e finalmente anulase. A relação entre o "Mestre" e o "nome", ser criador e ser criado, de

${ }^{12}$ Gn 2, 19. 
algum modo equivale à relação entre o sujeito do sopro e o soprar: em ambos se dilui o protagonista, de forma a transmutar-se o "Mestre" em nome e o sujeito do sopro em nome soprado: "Ele [...] transfunde os pulmões no vidro: / campânula e jarro são os pulmões do mundo". Resta a ausência de um protagonismo, a percepção de uma despersonalização, o entendimento de um caldeamento que se apresenta, enquanto disponibilidade, para ascender: foram dados os passos, criou-se o ambiente, potenciou-se o nome - por aproximação ao intertexto, pode dizer-se que talvez tenha chegado o final do sexto dia da criação.

O poema exige ainda, no contexto em que nos situamos, o levantamento de vocábulos ou expressões que se encontrem associadas semanticamente ao sopro: desde o terceiro verso do poema o "vidro" que é retirado do forno; a forma que lhe é incutida; a zona iluminada ao redor da cana, sendo este objecto o que liga o criador ao criado e proporciona o sopro intenso, para insuflar a forma no nome; "o vidro respira do que ele respirou"; "dá-lhe um baptismo novo"; "pneuma em cheio na estrela"; "transfunde os pulmões no vidro / [...] os pulmões do mundo". Aproximando estes elementos que foram recolhidos directa ou indirectamente e de forma sequenciada de modo a entendermos a progressão do poema, começam-se a entender novas relações vocabulares: a criação torna-se possível através da acção do fogo purificador; a cana, enquanto capaz de transmitir a energia do criador ao objecto, transforma-se num elemento essencial; a comunhão entre o criador e o criado e, por outro lado, a elevação e expansão deste ao espaço cósmico. Não se entenda, porém, que essa expansão se inscreve num espaço exterior ou concreto - mesmo que amplo, o movimento consegue-se sempre no sentido do interior, do ambiente mais denso, numa espécie de buraco negro, pleno de energia: "Que centro? / que movimento? Uma volta atmosférica num astro uma / volta do astro no forno uma volta no forno / em si mesmo", e aí situar-se-á a "zona iluminada" de um brilho intenso e obscuro. O último verso do poema concede, ao processo criativo que procurámos abordar, uma espécie de aura sagrada, tendo para o efeito associado o sopro da criação poética ao sopro genesíaco e terminando precisamente com a referência aos efeitos conseguidos pelo "vento de Deus", de modo a que possa brotar das coisas o ouro, produto de um processo alquímico que se mantém como procura do "nome do prodígio", "até que o vento tudo / sopra nessa lição até que / o irradiante os gestos magnificam / as formas do ar no ouro: a seara astronómica" (p. 581). 


\section{Sentidos do movimento e movimentos com sentido}

O movimento pode entender-se como a consequência ou o reflexo directo do reconhecimento de uma necessidade perante a percepção de uma ausência ou de vários excessos. Associadas a essa percepção, desenvolvem-se opções com direcções aparentemente diversas, sempre afastadas, nesta poesia, de emotividades imediatas conseguidas através de estáveis espaços da palavra. Aqui, os movimentos inscrevem-se em estruturas relacionais que se distanciam das associações comuns e sugerem inúmeras possibilidades de interpretação. Essa diversidade mantém, no entanto, determinados ritmos, opções revisitadas quase que ciclicamente de forma a permitirem uma leitura produtiva desses movimentos vocabulares. Para abordarmos os poemas que constituem Os selos, outros, últimos segundo a perspectiva do movimento, necessitamos de reduzir os sentidos do movimento e a área semântica dos elementos implicados de forma a tornar viável o seu entendimento: valorizar-se-ão os movimentos de associação entre as presenças vocabulares identificadoras de laços familiares, situados simbolicamente em pólos opostos, e os movimentos verticais, com o objectivo de entendermos relações produtivas, ainda, entre a perspectiva genesíaca que conduziu o desenvolvimento das páginas anteriores e os sentidos do movimento. Os primeiros versos do primeiro dos seis poemas esclarecem, desde logo, a perspectiva selectiva que referíamos. As mães, que pelo plural impõem um corte com qualquer tipo de relação pessoal, assumem como entidade abrangente, dominadora, a base de um conhecimento primordial capaz de iniciar os filhos que se queiram submeter a essa influência ou desenvolver esse obscuro conhecimento do mundo.

Se mexem as mãos memoriais as mães

transmudam

o mundo. Sabem ponto

a ponto forte o quotidiano estelar das matérias: aço, louça

- atrás do ramo

dos ouros a fruta iluminada nos sítios

onde lhe pegam. Elas

sabem como se enxameiam as coisas como vão de umas às outras ou se intensificam na limalha

por uma risca eléctrica. [...] (p. 575). 
Valoriza-se o conhecimento do toque, enquanto capacidade de ampliar os sentidos culturalmente impostos, busca-se o excesso das imagens, a deslocação ou a transferência do protagonismo: as "mãos" das mães mantêm sobre pressão o atributo "memoriais", embora o preparem para a explosão do movimento, ou seja, intensifica-se a palavra pela contenção que se lhe impõe. A exposição ou o esclarecimento sobre o conhecimento que as mães dominam pelo toque esclarece o excesso do "quotidiano estelar das matérias". A transmutação da matéria ou da visão que se tem da mesma matéria, o movimento interno ou a alteração em termos de conhecimento da matéria serão conseguidos à custa dessa atenção excessiva, do toque das "mãos memoriais": "a fruta iluminada nos sítios / onde lhe pegam" lembra a atitude de Eva, no Génesis, quando recolhe da árvore do paraíso o fruto que é "precioso para esclarecer a inteligência". ${ }^{13}$ Aquele conhecimento não se guia pela compreensão clarificadora, mas pela invasão e anulação da especificidade física da matéria, daí o gosto especial pelas palavras "coisa" e "objecto" que depuradas das suas circunstâncias se podem inscrever no mundo inaugural da matéria ainda sem nome, ainda em movimento e fricção: "sabem como se enxameiam as coisas como vão de umas às outras". Este movimento é essencialmente de depuração, promove a captação da essência "estelar das matérias" e só as "mães" que transportam a sabedoria dessa abordagem ancestral podem transmitir aos filhos o verdadeiro conhecimento da matéria e dos nomes.

À medida que nos encaminhamos para o final dos seis poemas, verifica-se uma gradual ausência de necessidade de se realçar a presença de um eu; no quinto poema, transfere-se o protagonismo para a terceira pessoa e segunda a quem o ele se dirige; no último poema ficamos somente perante a segunda pessoa, representando uma clara opção do poeta: a terceira pessoa evidenciaria uma maior proximidade à primeira pessoa, dado que ainda se poderia entender aquela como um eu, enquanto que o tu será em definitivo o receptor de um eu que se inibe em absoluto ao longo do último poema do livro. Do excerto que se segue e ao longo de alguns dos poemas em estudo torna-se evidente uma construção propositadamente rudimentar quanto às funções do narrador, como se se pretendesse desenvolver uma construção dialógica que

${ }^{13} \mathrm{Gn} 3,6$. 
reflectisse uma estrutura simples, a fim de destacar somente a sua componente simbólica para não distrair o seguimento do diálogo, com variações que só iriam retirar a força das ideias dos interlocutores, optando somente pelo "disse" e "respondeu" como representação da necessidade de respostas para as questões levantadas.

Ele disse que

quando

lhe tocava nas zonas quentes a luz do vento abria as searas profundas encapelava o ouro, os corredores do ar através das palavras - perguntou:

porquê? O sangue bate mão na mão, perguntou se aquilo era tocar em

disse: toco num objecto ele brilha

tudo,

objectos que se crispam perguntou se os objectos eram espasmos

do espaço. Disse, os corpos são varas de ouro plantadas.

A seiva rutila nelas. Tocava, abalava organismos, elementos

límpidos, varas vivas.

$\mathrm{O}$ ar sem fundo erguia-se de dentro dos sítios. Disse:

o génio ininterrupto de multiplicares

o teu espaço luminoso - e

cada vara brilha de si mesma e da outra vara próxima.

Em que recessos te queimo, virgens, em que

inexplicáveis redes de imagens

buracos

de vento nas searas eriçadas varas com força? (p. 583).

Este diálogo facilita a transmissão de conhecimento à custa da presença de alguém que se encontra perante a necessidade de compreender o sentido obscuro das coisas. Reforçam-se algumas presenças já destacadas no terceiro poema de Os selos, outros, últimos: a transmissão de energia pelo toque, um modo de eliminar os limites dos objectos. Estes versos como que assumem uma perspectiva didáctica ao explicarem, para além do efeito do toque sobre os corpos, a estrutura interna desses objectos e o modo como eles são vistos como uma totalidade não circunscrita ao limite material que a sua forma lhes parece impor. Há mesmo nesta visão uma compreensão genesíaca, dado o modo como são entendidos os corpos e os objectos, em constante contacto com o que neles transcende a matéria que os limita: a essência deles é o próprio caos que estava na sua origem e simultaneamente a perfeição que se situa por detrás da imagem física que transmitem. O enigma dos 
objectos e dos corpos, a sua energia oculta aproxima a cada momento o início da vida e a morte; indiferentes ao tempo em que se situam carregam consigo essa eternidade capaz de explicar a origem e o caos, "o angélico e o demoníaco" (p. 579). Esta energia que de algum modo representa o espírito dos corpos e dos objectos encontra-se parcialmente identificada com o ar e com o vento (recorde-se o sopro da vida): "a luz do vento abria as searas profundas / encapelava o ouro". O distúrbio provocado pelo movimento do ar (leia-se: capacidade criadora da palavra poética) ilumina os objectos, destaca deles o ouro, a essência e a perfeição representadas pelo metal conseguido à custa das transmutações do processo alquímico e neste processo o brilho significa intensidade, excesso de energia reunida para que se verifique a purificação: o brilho mantém-se ao longo de todo o percurso vertical em que os corpos e os objectos transitam: "os corpos são varas de ouro plantadas. / A seiva rutila nelas". O tempo está neles, vivem intensamente pela memória, trazem consigo a disponibilidade e a capacidade de elevação: "os objectos eram espasmos / do espaço [...] os corpos são varas de ouro".

Começámos com a referência às mães e terminamos do mesmo modo. Para além da mãe é ao elemento feminino que nos referimos, com toda a carga simbólica que possui e com o sentido genesíaco que lhe está subjacente. A mulher como a origem da vida, mas também como o princípio do pecado (relacionado com o excesso, pela ingestão do fruto), como podemos ler no Génesis, "Vendo a mulher que o fruto da árvore devia ser bom para comer, pois era de atraente aspecto, e precioso para esclarecer a inteligência, agarrou do fruto, comeu, deu dele a seu marido, que estava junto dela, e ele também comeu. Então, abriram-se os olhos aos dois [...]", ${ }^{14}$ depois de simbolizar o caos representará, como mãe, o princípio da redenção - recorde-se o Apocalipse: "Depois, apareceu um grande sinal no Céu: uma mulher revestida de Sol, tendo a Lua debaixo dos seus pés e uma coroa de doze estrelas sobre a cabeça. Estava grávida, com dores de parto, e gritava com ânsias de dar à luz". ${ }^{15}$ A evolução alquímica pressupõe a existência de três fases que de forma breve se podem denominar por obra a negro, a branco e finalmente a vermelho: à primeira corresponde o momento de destruição, à segunda o de

\footnotetext{
${ }^{14}$ Gn 3, 6-7.

${ }^{15}$ Ap 12, 1-2.
} 
depuração e à terceira está associado o momento da perfeição. O ouro será conseguido na última fase, depois de concluído o processo interior de transmutações e de anulação da matéria impura.

Quando a substância apure e arrefeça que inunde a boca a estrela

te inunde todo. Danças às vezes nas voragens - pelo poder desse arrebatamento movem-se: a cobra enrolada e a laranjeira ao meio dos meteoros e as mães nos tronos dos territórios silenciosos áureas mães aracnídeas ferrando os ganchos nos tecidos suaves rasgando nos tecidos os orifícios vermelhos. As mães devoram-te nos imos, como as devoras às cegas e as laranjas na boca profundamente com seu nome pleno a ouro bravio [...] (p. 585-586).

Este excerto do sexto e último poema de Os selos, outros, últimos apresenta sugestivamente, nos primeiros versos citados, a fase de arrefecimento da matéria, o termo de um percurso alquímico, onde os opostos se anulam, onde a boca e estrela se indefinem, onde o alto e o baixo, o visível e o obscuro se intensificam.

São, afinal, os sentidos do movimento, a dança e o arrebatamento, a elevação e o toque, o desenho circular da "cobra enrolada" ou da árvore que na sua posição vertical aproxima a terra do céu (atente-se no excerto à referência às laranjas pela circularidade da forma e pela cor de fogo), os elementos terra e ar, enquanto as mães se elevam "áureas", "nos tronos dos territórios silenciosos". A dança, que reúne de forma ritual os espaços com a anulação dos tempos, arrebata e eleva, unifica como que representando sugestivamente o momento iniciático, à semelhança do que sucedia nas culturas ancestrais. As mães simbolizam o início e o fim, devoram os filhos e são devoradas por eles (recorde-se "Saturno devorando um filho" de Goya, quadro escolhido pelo poeta para a capa de Ou o poema contínuo: súmula), fecha-se o círculo, sela-se o livro da vida ou quebram-se os selos, até porque as duas acções talvez sejam uma e a mesma atitude, como já tivemos oportunidade de referir. 


\section{A poesia como aliança, acto absoluto}

Poesia toda e Ou o poema contínuo, títulos atribuídos à obra poética de Herberto Helder (o primeiro até à edição de 1996 e o segundo a partir dessa edição), representam a ideia de totalidade e de continuidade mesmo que o espaço físico do livro não comporte toda a sua poesia. ${ }^{16}$ Esta é sempre toda e contínua, é uma poesia de inclusão, elimina as fronteiras, perturba os sentidos das palavras - tudo é o todo, não interessam os limites dos objectos, mas a ausência desses limites, os pontos de fuga de cada objecto e o modo como se contaminam as coisas, na frase.

As opções de estilo são absolutamente concordantes com o sentido de um e de outro título; as metáforas de metáforas, ${ }^{17}$ tal como se vão sequenciando no verso, criam elos semânticos que anulam sentidos comuns e exigem combinações impostas pela palavra colocada no sintagma; a carga simbólica exige para além do sintagma a recorrência a uma combinação que, ultrapassando o sintagma, lida com a complexa decifração do símbolo, enquanto capaz de comportar sentidos ambivalentes. Nesta amálgama, neste espaço caldeado reúnem-se as palavras e formam-se os versos para que a cada novo poema se vá mais fundo, numa construção espiralada em profundidade, onde a poesia é sempre toda e contínua. Podemos encontrar igual concordância, por exemplo, nas opções de pontuação ou na sua propositada ausência com o objectivo de criar espaços de fricção semântica, anulação de sentidos, através da perturbação das pausas naturais entre os sintagmas.

Aquela imagem de totalidade que recrudesce a cada novo poema é também o resultado da relação profunda que o poeta cria entre a poesia e o corpo, sendo a boca um espaço privilegiado para realçar essa potencialidade bipolar. A mãe, assim como a boca, assume também aqui, como tivemos oportunidade de referir, um estatuto privilegiado, dado que cria o filho e a palavra; esta identificação do filho e da palavra como elementos que brotam da mãe abrem para uma outra relação, onde o filho, capaz de criar a palavra, se identifica com a capacidade criadora da

\footnotetext{
${ }^{16}$ Não constam de um ou de outro, entre outros textos, os livros publicados em 1997 de "Poemas Mudados para Português": Ouolof, Doze nós numa corda e Poemas amerindios.

${ }^{17}$ Cf. HELDER, 1996, p. 349.
} 
mãe, fechando-se, assim, o triângulo da sabedoria com a correspondência simbólica entre mãe, filho e palavra.

"A poesia é um baptismo atónito, sim uma palavra / surpreendida para cada coisa" (p. 565) e na surpresa da nomeação da palavra, no encontro entre o nome e a coisa reside o verdadeiro conhecimento, enquanto realização poética. Há, todavia, o reconhecimento de que para se desenvolver o percurso de forma a aceder ao espaço em que as palavras se elevam para dizer a totalidade é necessária uma disponibilidade constante e um trabalho árduo de atenção.

"O vagar magnifica. Como no alongamento dos ofícios, atenção, os ritmos / - e se a bebida é tão íntima numa infusa / que / em mente e sede se torna / acto / absoluto, aliança, poesia" (p. 576). O poeta concede uma enorme atenção aos pormenores e entende-se esse cuidado através de um estilo que se constrói à custa de opções que se mantêm. A atenção à porta das coisas, a procura dos sentidos perdidos é desenvolvida com aquele "vagar" que "magnifica": é a própria disponibilidade que permite o enaltecimento da matéria, das coisas e do corpo, a captação da respiração dos objectos. Dá-se a comunhão dos elementos, imiscui-se o olhar, invadem-se as coisas com o toque, perde-se a identidade do corpo no contacto com os corpos. A viagem que se faz é cada vez mais no sentido da profundidade, desce-se aos espaços recônditos e obscuros, às vísceras do corpo e da palavra e de tal modo é a entrega do sujeito lírico ao percurso que desenvolve que se indiferencia com ele e se anula nele e "se torna / acto / absoluto, aliança, poesia".

A bebida numa infusa, pela cumplicidade que cria com o objecto, origina a percepção de sede e a própria sede e essa comunhão e equilíbrio de estados criam o momento absoluto, mas podem também as "Águas agrestes", pela força que transmitem, arrebatar o corpo, elevá-lo, colocá-lo em situação de comunhão pela pulverização dos traços que o identificam.

\author{
[...] Águas agrestes minam-te até à transparência e ergues-te \\ obra o torso \\ vibrando \\ com as rosas das cicatrizes. É essa coisa que fazes \\ obscuramente - se um dia és lenha suada ardes \\ da tua própria resina se \\ torneias o vaso dás-lhe pela cinta quieta \\ uma pancada salgada um donaire \\ de onda, e tocas na curva da bilha: e ficas harmonioso - (p. 586).
}


A possibilidade de conseguir a harmonia está sujeita à concretização de diversas condições situadas no espaço do corpo, caracterizadas por uma simbologia associada ao fogo que destrói e anula, ao sal, elemento que conserva e purifica, fogo e sal associados a elementos circulares como o vaso, onda e curva da bilha. A harmonia consegue-se pelo toque, como vimos noutros momentos, com a "pancada salgada" ou "na curva da bilha": reunidas todas as condições, ultrapassadas as fases do processo, "ficas harmonioso", e com essas palavras termina o livro e selam-se os selos.

\section{Selam-se as palavras ou uma conclusão}

A poesia de Herberto Helder inibe as palavras ligeiras, não condescende com a paráfrase e dificilmente proporciona uma coerência fácil ao discurso crítico. O excesso de sentidos que perturba a compreensão pode também representar a aproximação ao silêncio e nestes poemas como que os selos assumem esse diálogo complexo com aquele silêncio. A complexa combinação de sentidos não inviabiliza o convívio, pelo contrário, promove um adensamento enriquecedor e uma disponibilidade incontida para novos sentidos. Dessa combinação complexa demos sinal, quando, dentro do mesmo texto, entendemos o diálogo intertextual com o Apocalipse com o Génesis, compreendendo a presença e a necessidade do caos e da morte assim como da criação e da vida.

A capacidade criadora da palavra e do sintagma verbal por aproximações e combinações inesperadas de vocábulos, que se inscrevem num conjunto limitado de áreas vocabulares, anela por sentidos mais profundos, enquanto representação das coisas e do corpo, no seu fundo mais oculto e enigmático. A presença recorrente de alguns vocábulos reforça a importância de determinados temas como aqueles que se inscrevem nas relações entre mãe, filho ou criança; elementos astronómicos e aéreos como estrelas e ar, objectos como árvores, promovem aproximações ciclicamente revisitadas ao longo da poesia do autor.

No décimo segundo poema de Os selos, evidencia-se a necessidade do selo sobre as palavras e sobre o corpo, "Tranca-me numa pedraria / vibrante. Para que eu me revele em mim. E me sele nas palavras com veias" (p. 570) e todo o percurso dos dezoito poemas mantém essa perspectiva para que se possa entender uma consonância do corpo com 
as coisas, distante da superficialidade e do seu entendimento. Por isso se afastam abordagens epidérmicas que distraem, sela-se o corpo para que ele se revele, selam-se os sentidos para que as palavras possam anunciar a harmonia e a totalidade.

\section{Referências}

BÍBLIA SAGRADA. 11. ed. Lisboa: Difusora Bíblica, 1984.

CHEVALIER, Jean; GHEERBRANT, Alain. Dicionário de símbolos. 6. ed. Rio de Janeiro: José Olympio, 1992.

COELHO, Eduardo Prado. O doce terror das imagens. Jornal de Letras, Artes e Ideias, 1 fev. 1994, p. 17.

COELHO, Eduardo Prado. Velocidade e efeitos especiais. Jornal de Letras, Artes e Ideias, 26 out. 1994, p. 40-41.

DAL FARRA, Maria Lúcia. A alquimia da linguagem: leitura da cosmogonia poética de Herberto Helder. Lisboa: Imprensa Nacional/Casa da Moeda, s/d.

DIOGO, Américo António Lindeza. Herberto Helder texto, metáfora, metáfora do texto. Coimbra: Livraria Almedina, 1990.

FREITAS, Manuel de. Uma espécie de crime: apresentação do rosto de Herberto Helder. Lisboa: \& Etc, 2001.

FURTADO, Maria Teresa Dias. A dialéctica do silêncio em Herberto Helder. Colóquio/Letras, n. 35, p. 73-76, jan. 1977.

GARCIA, Mário. Poesia Toda, de Herberto Helder - uma apresentação. Brotéria, n. 133, p. 92-97, 1991.

GARCIA, Mário. Um itinerário para Deus, em quatro livros da poesia portuguesa contemporânea. In: O Padre António Vieira e outros poetas. Braga: Faculdade de Filosofia, 2000. p. 223-234. (Estudos Humanísticos, 3).

GUEDES, Maria Estela. Herberto Helder poeta obscuro. Lisboa: Moraes Editores, 1979. (Margens do Texto, 8).

HELDER, Herberto. Os passos em volta. 6. ed. Lisboa: Assírio \& Alvim, 1994 .

HELDER, Herberto. Do mundo. Lisboa: Assírio \& Alvim, 1994b.

HELDER, Herberto. Poesia toda. Lisboa: Assírio \& Alvim, 1995.

HELDER, Herberto. Photomaton \& Vox. 3. ed. Lisboa: Assírio \& Alvim, 1996. 
HELDER, Herberto. Doze nós numa corda (poemas mudados para português por Herberto Helder). Lisboa: Assírio \& Alvim, 1997.

HELDER, Herberto. Ouolof (poemas mudados para português por Herberto Helder). Lisboa: Assírio \& Alvim, 1997.

HELDER, Herberto. Poemas ameríndios (poemas mudados para português por Herberto Helder). Lisboa: Assírio \& Alvim, 1997.

HELDER, Herberto. Ou o poema contínuo (súmula). Lisboa: Assírio \& Alvim, 2001. (Grãos de Pólen, 2).

HELDER, Herberto. Ou o poema contínuo. Lisboa: Assírio \& Alvim, 2004.

LOPES, Silvina Rodrigues. A inocência do devir. Lisboa: Edições Vendaval, 2003.

MAGALHÃES, Joaquim Manuel. Herberto Helder. In: Um pouco de morte. Lisboa: Editorial Presença, 1989. p. 125-136.

MARINHO, Maria de Fátima. Herberto Helder: a obra e o homem. Lisboa: Editora Arcádia, 1982.

MARTINS, Manuel Frias. Um silêncio de bronze. Lisboa: Livros Horizonte, 1983.

PERKINS, Juliet. The feminine in the poetry of Herberto Helder. London: Tamesis Books, 1991. (Tamésis, serie A: Monografías, 144).

SARMENTO, Jacinta. La poésie de Herberto Helder: demesure et rigueur. In: Arquivos do Centro Cultural Português, v. 20. Lisboa-Paris: Fundação Calouste Gulbenkian, 1984. p. 149-216.

SILVA, João Amadeu Oliveira Carvalho da. Os "Poemas mudados para português" de Herberto Helder - uma epopeia da palavra. Brotéria, n. 147, p. 163-200, ago.-set. 1998.

SILVA, João Amadeu Oliveira Carvalho da. Entre o Húmus de Raul Brandão e o Húmus de Herberto Helder. Revista Portuguesa de Humanidades, Braga, Faculdade de Filosofia da Universidade Católica Portuguesa, v. 2, n. 1-2, p. 287-315, 1998.

SILVA, João Amadeu Oliveira Carvalho da. Os selos de Herberto Helder: entre a apresentação do rosto e a biografia rítmica. Braga: Publicações Faculdade de Filosofia da UCP, 2000. (Estudos Humanísticos, 2)

SILVA, João Amadeu Oliveira Carvalho da. A poesia de Herberto Helder- Do contexto ao texto: uma palavra sagrada na noite do mundo. Lisboa: Fundação Calouste Gulbenkian/ Fundação para a Ciência e a Tecnologia, 2004. 


\section{Resumo}

Após nossa leitura de Os selos, de Herberto Helder, desenvolvemos o estudo de Os selos, outros, últimos, série composta de seis poemas pertencentes ao mesmo "impulso de escrita" daquela anterior. À relação intertextual entre os dois conjuntos de poemas e o Apocalipse, inserimos um diálogo com o Génese, traçando, dessas relações situadas entre caos e criação, a idéia de uma marca indelével da poética imaginária do autor.

\section{Abstract}

Following our reading of Herberto Helder's Os selos, we now develop the study of Os selos, outros, últimos, which consists of six poems belonging to the same "impulso de escrita" ("writing impulse") of the previous collection. To the intertextual relation between the two sets of poems and the Apocalypse, we add an equally interesting dialogue with the Genesis, drawing from those relations placed between chaos and creation the idea of an identified movement between opposites, in a direction of ascension and depth, an indelible mark of the poetic imaginary of the author. 